\title{
SUBSTITUSI TEPUNG BUNGKIL KEDELAI DENGAN FERMENTASI DAUN LAMTORO (Leucaena glauca) TERHADAP PERTUMBUHAN DAN EFISIENSI PAKAN IKAN NILA (Oreochromis niloticus)
}

\section{SUBTITUTION OF SOYBEAN MEAL WITH FERMENTED LAMTORO (Leucaena glauca) ON GROWTH AND FEED EFFICIENCY OF TILAPIA FISH (Oreochromis niloticus)}

\author{
Novi Krishatno Putera, Agustono dan Sri Subekti \\ Fakultas Perikanan dan Kelautan Universitas Airlangga \\ Kampus C Mulyorejo - Surabaya, 60115 Telp. 031-5911451
}

\begin{abstract}
Tilapia fish (Oreochromis niloticus) was known as an important commodity in the world's freshwater. Tilapia fish (O. niloticus) was a omnivores species of fish, which means that can eat plants and animals. Tilapia fish easy to breed, fast growing, relatively has large body size, disease resistance, easy to adapt to the environment, the price was relatively cheap and has a high nutritional value as a source of animal protein. One of the obstacles faced in the feed manufacturing was an expensive raw material availability, therefore, necessary to find alternative feed ingredients that were cheap, quality and be available at all the times.

The purpose of this study was to determine the effect of the use lamtoro were fermented with probiotic on growth and feed efficiency of tilapia fish. The research was conducted at the Faculty of Fisheries and Marine University. This study was conducted for 42 days from 25 March - 5 May 2013. The research design used was a completely randomized design (CRD).

Materials used in this study was tilapia fish aged 1 month, the body length ranges between 3-5 $\mathrm{cm}$ and body weight ranged from 1,3-1,5 gram as 100 individuals. Form of feed pellets substituted with lamtoro fermented dose A. $0 \%$ (control), B. $10 \%$, C. $20 \%$, D. $30 \%$, E. $40 \%$ with 4 replications. The main parameters observed in this research were the growth rate and feed efficiency. Support parameters was the quality of water.

Based on the results of research about substitution of soybean meal with fermented lamtoro in the feed rations were no significantly different effect on the rate of growth and feed efficiency (p>0.05) due to dissolved oxygen content does not qualify as well as, higher quality feed than feed quality substituted.
\end{abstract}

Keywords : Oreochromis niloticus, Leucaena glauca, growth, feed efficiency

\section{Pendahuluan}

Ikan nila (Oreochromis niloticus) dikenal sebagai komoditas air tawar penting di dunia. Ikan nila merupakan jenis ikan omnivora, artinya dapat memakan tumbuhan maupun hewan (Wardoyo, 2007). Ikan nila mudah berkembang biak, pertumbuhannya cepat, ukuran badan relatif besar, tahan terhadap penyakit, mudah beradaptasi dengan lingkungan, harganya relatif murah dan mempunyai nilai gizi yang cukup tinggi sebagai sumber protein hewani (Agustono dkk, 2009).

Salah satu kendala yang dihadapi dalam pembuatan pakan tersebut adalah ketersediaan bahan baku yang mahal karena masih diimpor dari luar negeri, oleh karena itu, perlu dicari bahan baku pakan alternatif yang murah, berkualitas, dan dapat tersedia sepanjang waktu. Lamtoro adalah tumbuhan leguminosa daerah tropis dan berasal dari Amerika Tengah.
Di Indonesia dikenal dengan nama petai cina, petai metir, peuteuy selong dan kemlandingan (Wisadirana, 1982 dalam Sarmanu, 1986). Komposisi kimia daun lamtoro, yaitu berat kering 97,8923\%; protein kasar 23,8326\%, bahan ekstrak tanpa nitrogen (BETN) $31,0509 \%$, serat kasar $23,5877 \%$, lemak $11,6858 \%$ dan abu 7,7353\% (Putri, 2012), oleh karena itu perlu dilakukan proses fermentasi agar kandungan serat kasar pada daun lamtoro turun.

Tujuan penelitian ini adalah mengetahui pengaruh penggunaan daun lamtoro yang difermentasi dengan probiotik terhadap pertumbuhan dan efisiensi pakan ikan nila. Penelitian ini diharapkan dapat memberikan informasi mengenai penggunaan daun lamtoro yang difermentasi dengan probiotik dalam ransum pakan terhadap pertumbuhan dan efisiensi pakan ikan nila. 


\section{Metodologi}

Penelitian dilaksanakan selama 42 hari pada bulan Maret sampai Mei 2013 di Fakultas Perikanan Dan Kelautan Universitas Airlangga.

Alat-alat yang digunakan dalam penelitian antara lain: akuarium, filter, seser/serok, selang, penggilingan, pengayakan, timbangan, baskom, alat pencetak pellet, oven, plastik, gunting, kertas, loyang, $\mathrm{pH}$ meter, termometer, dan DO meter.

Bahan baku pakan yang akan digunakan dalam penelitian ini adalah tepung fermentasi daun lamtoro, aquades, probiotik magoan, tepung jagung, CMC, tepung ikan, tepung bungkil kedelai, tetes tebu, vitamin dan mineral mix. Probiotik magoan diperoleh dari kerjasama antara Fakultas Perikanan dan Kelautan Universitas Airlangga dengan Petani Magoan Kepanjen Malang.

Ikan uji yang digunakan dalam penelitian adalah ikan nila yang didapatkan dari Pasar Ikan Gunungsari dengan umur 1 bulan, ukuran panjang tubuh berkisar antara $3-5 \mathrm{~cm}$ dan berat tubuh berkisar antara 1,3-1,5 gram. Jumlah ikan nila yang dibutuhkan 100 ekor yang dibagi dalam 20 akuarium.

Media pemeliharaan yang digunakan dalam penelitian ini adalah air tawar yang berasal dari PDAM dengan volume 10 liter per akuarium.

Penelitian ini menggunakan Rancangan Acak Lengkap (RAL) dimana semua dikondisikan sama kecuali perlakuan (Kusriningrum, 2008). Perlakuan yang digunakan adalah 5 perlakuan dengan 4 kali ulangan. Perlakuan yang diberikan adalah perbedaan dosis tepung fermentasi daun lamtoro dalam ransum pakan. Perlakuan tersebut adalah : A (0\%), B (10\%), C (20\%), D (30\%), E (40\%).

Ikan uji yang digunakan dalam penelitian adalah ikan nila yang didapatkan dari Pasar Ikan Gunungsari dengan umur 1 bulan, ukuran panjang tubuh berkisar antara $3-5 \mathrm{~cm}$ dan berat tubuh berkisar antara 1,3 - 1,5 gram. Ikan nila yang digunakan dalam penelitian ini adalah ikan yang sehat, tidak terserang penyakit dan homogen.

Daun lamtoro yang sudah dikeringkan kemudian difermentasi dengan probiotik magoan. Bahan baku pakan yang akan digunakan untuk perlakuan dilakukan analisis proksimat terlebih dahulu untuk mengetahui kandungan nutrisinya. Bahan baku pakan yang sudah dianalisis proksimat, kemudian dibuat pakan sesuai perlakuan dengan kandungan protein sebesar 30\%. Bahan penyusun pakan dianalisis proksimat terlebih dahulu untuk mengetahui kandungan nutrisinya. Kemudian pakan disusun sesuai dengan dosis yang telah ditentukan yaitu pemberian tepung fermentasi daun lamtoro 0\%, 10\%, 20\%, 30\%, $40 \%$. Setelah disusun sesuai dengan dosis yang telah ditentukan, pakan uji dibuat dalam bentuk pelet dan ukurannya disesuaikan dengan bukaan mulut ikan uji. Pelet yang telah jadi kemudian dianalisis proksimat lagi.

Persiapan penelitian meliputi meliputi persiapan akuarium dan air media pemeliharaan. Akuarium yang akan digunakan dalam penelitian ini disterilisasi terlebih dahulu dengan menggunakan klorin 400 ppm kemudian dibilas dengan menggunakan air bersih kemudian dikeringkan. Media pemeliharaan yang digunakan dalam penelitian ini adalah air tawar. Air tawar tersebut dimasukkan ke dalam 20 akuarium. Tiap akuarium diisi dengan air 10 liter.

Ikan lele ditempatkan di akuarium dengan 5 perlakuan, setiap perlakuan menggunakan 4 akuarium. Masing-masing akuarium diisi dengan 5 ekor ikan yang diadaptasikan terlebih dahulu selama 7 hari dengan tujuan adaptasi lingkungan yang baru dan beradaptasi dengan pakan uji agar ikan dapat makan sewaktu dilaksanakan penelitian. Setelah masa adaptasi selesai, ikan dipuasakan selama 24 jam dengan tujuan untuk menghilangkan pengaruh sisa pakan dalam tubuh ikan serta mengurangi stress pada ikan.

Parameter utama yang diamati dalam penilitian ini adalah laju pertumbuhan dan efisiensi pakan. Paramater penunjang berupa kualitas air. 


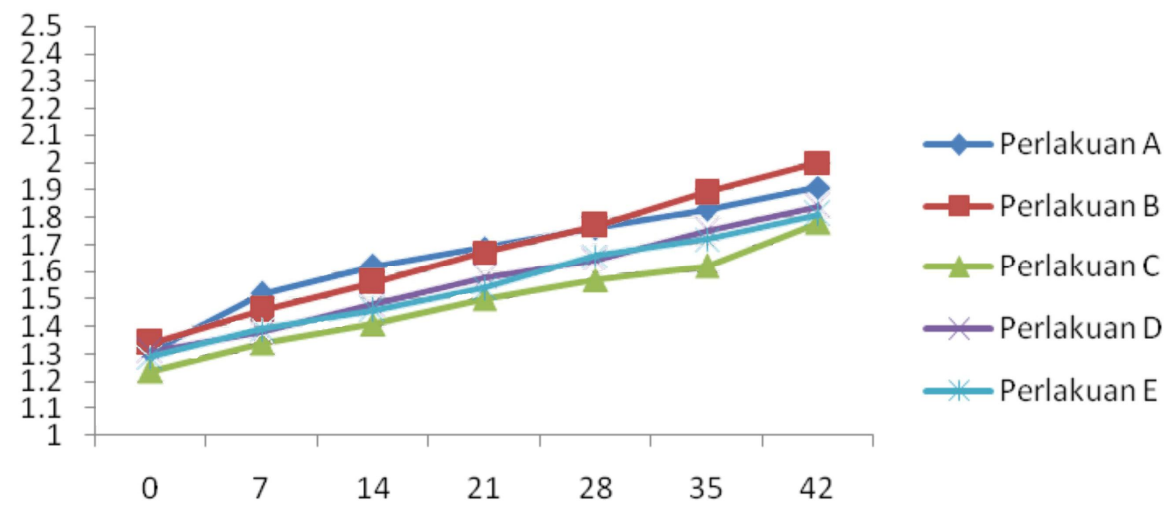

Gambar 1. Hubungan Lama Pemeliharaan Dengan Berat Rata-Rata Benih Ikan Nila

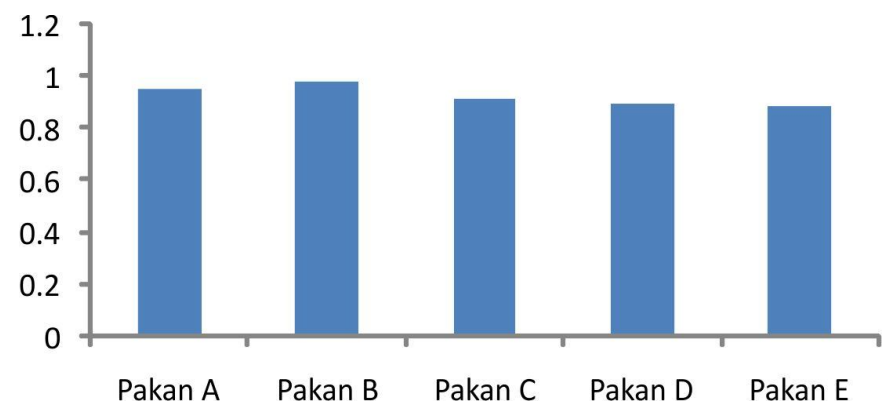

Gambar 2. Hubungan Pakan Perlakuan Dengan Laju Pertumbuhan Harian Benih Ikan Nila

Data yang diperoleh, diolah dengan menggunakan Analysis of Variant (ANOVA) untuk mengetahui pengaruh perlakuan. Apabila dari analisis ragam diketahui bahwa perlakuan menunjukkan pengaruh yang berbeda nyata, maka untuk membandingkan pengaruh perlakuan dilanjutkan Uji Jarak Berganda Duncan (Kusriningrum, 2008).

\section{Hasil dan Pembahasan}

Data rata-rata laju pertumbuhan harian ikan nila pada setiap perlakuan selama pemeliharaan 42 Hari dapat dilihat pada tabel 1 .

Tabel 1. Data Rata-Rata Laju Pertumbuhan Harian (\%) Ikan Nila Pada Setiap Perlakuan Selama Pemeliharaan 42 Hari

\begin{tabular}{|c|c|c|}
\hline Perlakuan & LPH $(\%) \pm$ SD & $\begin{array}{c}\text { Transformasi } \\
\sqrt{y}_{\mathrm{y}} \pm \mathrm{SD}\end{array}$ \\
\hline Pakan A & $0,90 \pm 0,2022$ & $0,95 \pm 0,11$ \\
Pakan B & $0,96 \pm 0,153$ & $0,98 \pm 0,0768$ \\
Pakan C & $0,85 \pm 0,2373$ & $0,91 \pm 0,1281$ \\
Pakan D & $0,81 \pm 0,1775$ & $0,90 \pm 0,0949$ \\
Pakan E & $0,80 \pm 0,0714$ & $0,89 \pm 0,0408$ \\
\hline
\end{tabular}

Keterangan :

$\begin{array}{ll}\text { LPH } & \text { : Laju Pertumbuhan Harian } \\ \text { SD } & \text { : Standar Deviasi }\end{array}$

Hasil rata-rata laju pertumbuhan harian ikan nila pada ke lima perlakuan diketahui pakan B memiliki rata-rata laju pertumbuhan tertinggi kemudian diikuti pakan $\mathrm{A}$, pakan $\mathrm{C}$, pakan D dan pakan E. Hasil analisis varian diperoleh tidak adanya perbedaan yang nyata terhadap pertumbuhan ikan nila $(\mathrm{F}$. Hitung $>\mathrm{F}$. Tabel 0.05).

Grafik hubungan antara lama pemeliharaan dengan berat rata-rata benih ikan nila dapat dilihat pada Gambar 1, sedangkan grafik hubungan antara perlakuan dan laju pertumbuhan harian benih ikan nila dapat dilihat pada Gambar 2.

Data rata-rata efisiensi pakan ikan nila selama 42 hari pemeliharaan pada Tabel 2 
Tabel 2. Data Rata-Rata Efisiensi Pakan Benih Ikan Nila Selama 42 Hari Pemeliharaan

\begin{tabular}{|c|c|c|}
\hline Perlakuan & $\begin{array}{c}\text { Efisiensi pakan } \\
(\%) \pm \text { SD }\end{array}$ & $\begin{array}{c}\text { Transformasi } \\
\sqrt{y}_{\mathrm{y}} \pm \mathrm{SD}\end{array}$ \\
\hline Pakan A & $44,82 \pm 10,7939$ & $41,98 \pm 6,2844$ \\
\hline Pakan B & $46,86 \pm 7,4334$ & $8 \pm 4,2844$ \\
\hline Pakan C & $46,75 \pm 11,8458$ & $43,08 \pm 6,8759$ \\
\hline Pakan D & $45,43 \pm 7,8192$ & $42,36 \pm 4,513$ \\
\hline Pakan E & $48,51 \pm 3,3529$ & $44,15 \pm 1,9211$ \\
\hline
\end{tabular}

Pada tabel 2 menunjukkan bahwa pemberian pakan dengan fermentasi daun lamtoro tidak memberikan perbedaan efisiensi pakan pada benih ikan nila (F. Hitung $>$ F. Tabel 0.05), sehingga diketahui bahwa efisiensi pakan tertinggi didapat pada pakan perlakuan $\mathrm{E}$ yang diikuti pakan perlakuan $\mathrm{B}$, pakan perlakuan $\mathrm{C}$, pakan perlakuan $\mathrm{D}$ dan pakan perlakuan A. Grafik hubungan perlakuan dengan efisiensi pakan selama 42 hari dapat dilihat pada gambar 3 .

Data kisaran kualitas air selama 30 hari penelitian antara lain, suhu $26-29^{\circ} \mathrm{C}$, pH air 7 - 9, DO air 2 - $5 \mathrm{mg} / \mathrm{l}$, Amoniak 0,25 - 1,5 $\mathrm{mg} / \mathrm{l}$.

Laju pertumbuhan berkaitan erat dengan pertambahan bobot yang berasal dari penggunaan protein, lemak, karbohidrat dari pakan yang dikonsumsi ikan (Bardach et al., 1972). Laju pertumbuhan harian berfungsi untuk menghitung persentase pertumbuhan berat ikan per hari. Hasil analisis statistik menunjukkan bahwa laju pertumbuhan tidak berbeda nyata antar perlakuan $(p<0,05)$. Laju pertumbuhan tertinggi terdapat pada perlakuan B $(0,98 \%)$ dengan penggunaan fermentasi daun lamtoro $10 \%$. Laju pertumbuhan yang paling rendah ditunjukkan pada perlakuan $\mathrm{E}(0,89 \%)$ dengan penggunaan fermentasi daun lamtoro sebesar $40 \%$. Hal tersebut menunjukkan bahwa penggunaan fermentasi daun lamtoro dalam ransum pakan tidak dapat menunjukkan laju pertumbuhan yang lebih baik dibandingkan dengan penggunaan tepung bungkil kedelai. Pakan dengan perlakuan B menunjukan laju pertumbuhan tertinggi dikarenakan pakan tersebut memiliki kandungan energi tertinggi dibandingkan dengan perlakuan yang lain yaitu $3144,21 \mathrm{Kkal} / \mathrm{Kg}$, yang mana Digestibility Energy yang dibutuhkan ikan nila sebesar 2.500-4.300 Kkal/Kg (Jouncey dan Rose, 1982).

Pertambahan berat rata-rata pada ikan nila antar perlakuan pakan $\mathrm{A}, \mathrm{B}, \mathrm{C}, \mathrm{D}$, dan $\mathrm{E}$ tidak menunjukkan perbedaan yang nyata walaupun kadar energi pada pakan meningkat. Hal ini disebabkan karena pada saat pemeliharaan ikan nila kandungan oksigen terlarut (DO) berada di bawah batas minimal, yaitu $2 \mathrm{mg} / \mathrm{l}$, sehingga kemungkinan dapat memperlambat pertumbuhan ikan nila. Menurut pendapat Khairuman dan Amri (2008) bahwa oksigen terlarut yang dibutuhkan dalam budidaya nila minimal $3 \mathrm{mg} / \mathrm{l}$. Jika dilihat dari kualitas pakan, kandungan protein bungkil kedelai, yaitu $41,0323 \%$ lebih tinggi daripada kandungan protein fermentasi daun lamtoro, yaitu $34,782 \%$.

Pertumbuhan berkorelasi erat dengan sintesis protein, karena pertumbuhan merupakan perubahan jumlah zat komponen tubuh, dan pada ikan sebagian besar zat komponen tersebut dalam bentuk protein, lemak, dan karbohidrat (Brett \& Groves 1979 dalam Rosmawati 2005). Pertumbuhan ikan yang relatif lambat disebabkan karena kandungan energi pakan khususnya yang berasal dari karbohidrat dan lemak tidak cukup untuk proses metabolisme. Akibatnya protein digunakan untuk proses tersebut, sehingga protein dalam pakan tidak mencukupi bagi ikan untuk proses pertumbuhan.

Pertumbuhan ikan sangat tergantung kepada penggunaan energi dalam pakan. Penggunaan energi yang berfluktuasi, kondisi fisik ikan dan kondisi perairan sangat berpengaruh terhadap besarnya energi yang dikonsumsi oleh ikan sehingga menyebabkan adanya peningkatan dan penurunan energi tubuh (NRC 1993). Menurut Stickney (1979) dalam Pelawi (2003), energi yang terkandung dalam pakan yang berasal dari non-protein dapat mempengaruhi jumlah protein yang digunakan untuk pertumbuhan. Jika pakan kekurangan energi yang berasal dari non-protein maka sebagian besar protein yang seharusnya digunakan untuk pertumbuhan, akan dimanfaatkan sebagai sumber energi.

Pada penelitian ini jumlah pakan yang diberikan disesuaikan dengan kebutuhan ikan yaitu tiga persen dari berat tubuh ikan perhari. Komposisi pakan yang diberikan terutama pada kandungan protein sudah berada pada kisaran optimum yaitu sebesar $\pm 25 \%$. Hal ini sesuai dengan pendapat yang dikemukakan oleh Mudjiman (2004), bahwa umumnya ikan membutuhkan pakan yang kandungan proteinnya $20-60 \%$. Dari data tersebut diketahui bahwa perlakuan yang memberikan laju pertumbuhan tertinggi adalah B sebesar 0,98 , kemudian A yang mempunyai nilai ratarata pertumbuhan sebesar 0,95 , perlakuan $\mathrm{C}$ yang mempunyai nilai rata-rata pertumbuhan sebesar 0,91 . Selanjutnya perlakuan D nilai ratarata pertumbuhannya sebesar 0,9 dan perlakuan E mempunyai nilai rata-rata pertumbuhan sebesar 0,89. Suyanto (2010), menyatakan 
pertumbuhan yang cepat pada ikan nila rata-rata $2,1 \mathrm{~g} / \mathrm{hari}$, sehingga pada penelitian ini ratarata pertumbuhan masih di bawah rata-rata normal.

Efisiensi pakan diperiksa guna menilai kualitas pakan, semakin tinggi nilai efisiensi pakan membuktikan pakan semakin baik (Kordi, 2000). Efisiensi pakan merupakan kemampuan ikan untuk memanfaatkan pakan secara optimal. Hal ini terkait dengan kemampuan ikan untuk mencerna pakan yang diberikan kemudian menyimpannya di dalam tubuh. Semakin kecil nilai efisiensi pakan maka ikan tidak efisien dalam memanfaatkan pakan tersebut. Hasil penelitian ini menunjukkan bahwa pemberian pakan dengan kandungan energi yang berbeda-beda sebesar 2700,66 $3144,21 \mathrm{kkal} / \mathrm{kg}$ pakan tidak mempengaruhi efisiensi pakan pada ikan nila $(\mathrm{P}<0,05)$.

Tidak adanya perbedaan efisiensi pakan pada penelitian ini disebabkan karena laju pertumbuhan ikan tidak berbeda nyata dengan demikian menyebabkan efisiensi pakan sama. Selain itu pada penelitian ini diduga dipengaruhi oleh aroma pakan, karena penambahan daun lamtoro yang difermentasi sebelumnya diduga menyebabkan daya terima (palatabilitas) dari ikan menjadi berkurang. Rendahnya konsumsi pakan oleh ikan pada perlakuan, berarti juga menurunkan jumlah protein yang dimakan akibatnya protein yang disimpan menjadi protein tubuh juga rendah. Lovell (1988) dalam Adelina (1999) juga mengemukakan bahwa pakan yang berenergi tinggi karena keberadaan lemak yang tinggi menyebabkan konsumsi pakan ikan menjadi rendah.

Faktor penting penentu pertumbuhan dan efisiensi pemanfaatan pakan adalah jenis dan komposisi pakan yang sesuai dengan kebutuhan ikan. Jenis dan komposisi pakan harus sesuai dengan ketersediaan endoenzim dalam saluran pencernaan ikan, sehingga pakan akan dicerna dengan baik dan energi yang tersedia untuk pertumbuhan akan lebih besar. Untuk meningkatkan efisiensi pemanfaatan pakan maka dalam memformulasikan pakan perlu mempertimbangkan kebutuhan nutrisi dari spesies ikan yang akan dipelihara, diantaranya adalah kebutuhan energi, protein, karbohidrat, lemak, vitamin dan mineral (Watanabe 1988 dalam Rosmawati 2005).

Air merupakan media internal dan eksternal bagi ikan. Sebagai media internal, air berfungsi sebagai bahan baku untuk reaksi di dalam tubuh, pengangkut bahan makanan ke seluruh tubuh, pengangkut sisa metabolisme untuk dikeluarkan dari dalam tubuh dan pengatur suhu tubuh. Sebagai media eksternal, air berfungsi sebagai habitat ikan. Kualitas air merupakan salah satu faktor yang mempengaruhi tingkat kelangsungan hidup dan pertumbuhan ikan selama pemeliharaan. Kualitas air yang harus diperhatikan supaya ikan dapat tumbuh dan berkembang secara optimal adalah suhu, keasaman $(\mathrm{pH})$, oksigen terlarut dan amoniak (Zonneveld et al., 1991).

Suhu adalah faktor lingkungan yang berpengaruh terhadap kecepatan metabolisme tubuh ikan. Kecepatan metabolisme ikan akan berlangsung optimal pada suhu optimal (Philips, 1972). Perubahan suhu lingkungan menyebabkan perubahan energi untuk pertumbuhan, laju respirasi dan laju konsumsi oksigen. Suhu air selama penelitian berkisar antara $26-29^{\circ} \mathrm{C}$. Hal ini sesuai dengan pendapat Khairuman dan Amri (2003) bahwa suhu air optimal yang dibutuhkan ikan nila yaitu berkisar antara $25-30{ }^{\circ} \mathrm{C}$. Dengan demikian suhu media pemeliharaan masih memenuhi persyaratan.

Derajat Keasaman $(\mathrm{pH})$ air selama penelitian berkisar antara $7-9$. Hal ini sesuai dengan pendapat Arie (2007) bahwa kisaran pH yang diperlukan oleh ikan nila berkisar antara 7 - 9. Dengan demikian pH, pada media pemeliharaan masih memenuhi persyaratan.

Oksigen merupakan satu parameter yang sangat penting bagi selurah organisme dalam kehidupannya, dimana oksigen sangat diperlukan untuk pernapasan dan metabolisme ikan. Oksigen terlarut (DO) dalam media air selama penelitian berkisar antara $2-5 \mathrm{mg} / \mathrm{l}$. Hal ini sesuai dengan pendapat Khairuman dan Amri (2008) bahwa oksigen terlarut yang dibutuhkan dalam budidaya nila minimal 3 $\mathrm{mg} / \mathrm{l}$. Dengan demikian oksigen terlarut dalam media pemeliharaan tidak memenuhi persyaratan.

Konsentrasi amoniak selama penelitian berkisar antara 0,25-1,5 mg/l. Khairuman dan Amri (2008) menyatakan bahwa batas amoniak dalam perairan yang dapat membahayakan ikan apabila kadar amoniaknya melebihi $0,5 \mathrm{mg} / \mathrm{L}$ air. Dengan demikian kandungan amoniak dalam media pemeliharaan tidak memenuhi persyaratan bagi kehidupan benih ikan nila.

\section{Kesimpulan}

Penggunaan fermentasi daun lamtoro sebagai substitusi tepung bungkil kedelai pada pakan dengan persentase yang berbeda tidak memberikan pengaruh nyata terhadap peningkatan pertumbuhan ikan nila. Data tertinggi adalah perlakuan B sebesar 0,98 dan data terendah perlakuan $\mathrm{E}$ dengan nilai rata-rata pertumbuhan sebesar 0,89 . Penggunaan 
fermentasi daun lamtoro pada pakan buatan dengan persentase yang berbeda tidak memberikan pengaruh nyata terhadap efisiensi pakan ikan nila. Data tertinggi adalah perlakuan E sebesar 44,15 dan data terendah perlakuan A dengan nilai rata-rata pertumbuhan sebesar 41,98 .

Perlu dilakukan penelitian ulang dengan memperhatikan kualitas air pada saat pemeliharaan ikan nila agar hasil yang diketahui lebih optimal. Selain itu, perlu dilakukan penelitian lebih lanjut apakah fermentasi daun lamtoro tersebut benar-benar terserap oleh ikan atau tidak.

\section{Daftar Pustaka}

Adelina. 1999. Pengaruh Pakan Dengan Kadar Protein dan Rasio Energi Berbeda Terhadap Pertumbuhan Benih Ikan Bawal Air Tawar (Colossoma macropomum). Tesis. Pasca Sarjana. IPB. Bogor.

Agustono, M. Hadi, dan Y. Cahyoko. 2009. Pemberian Tepung Limbah Udang Yang Difermentasi Dalam Ransum Pakan Buatan Terhadap Laju Pertumbuhan, Rasio Konversi Pakan Dan Kelangsungan Hidup Benih Ikan Nila (Oreochromis niloticus). Jurnal Ilmiah Perikanan Dan Kelautan Vol. 1. Fakultas Perikanan Dan Kelautan. Universitas Airlangga. Surabaya. hal 6.

Arie, U. 2007. Pembenihan dan Pembesaran Nila Gift. Cetakan Keenam. Penebar Swadaya. Jakarta. hal 7-79.

Bardach, J. E., J. H. Ryther and W. C. McLarney. 1972. Aquaculture. Willey Inter-Science. New York. P 98-105.

Jouncey, K. And B, Ross. 1982. A Guide to Tilapia Feeds and Feeding Institute of Aquaculture. University of Stirling. Scotland.

Khairuman dan K. Amri. 2003. Budidaya Ikan Nila Secara Intensif. Agromedia Pustaka. Depok. hal 141.

Khairuman dan K. Amri. 2008. Budidaya Ikan Nila Secara Intensif. Agromedia Pustaka. Jakarta. hal 7.

Kordi, M. G. H. K.. 2000. Budidaya Ikan Nila di Tambak Sistem Monosex Kultur. Cetakan Kedua. Dahara Prize Effhar Offset. Semarang. hal 280.

Kusriningrum, R. S. 2008. Perancangan Percobaan. Universitas Airlangga. Surabaya. hal. 43-63.

Mudjiman, A. 2004. Makanan Ikan. Penebar Swadaya. Jakarta. hal 104.
National Research Council (NRC). 1993. Nutrient Requirement of Fish. Washington DC : National Academy of Sciences.

Pelawi T. L. 2003. Pengaruh Pemberian Daphnia sp. yang Diperkaya dengan Minyak Ikan, Minyak Jagung dan Minyak Kelapa Terhadap Pertumbuhan dan Tingkat Kelangsungan Hidup Larva Ikan Nila (Oreochromis niloticus). Skripsi. Departemen Budidaya Perairan. Fakultas Perikanan dan Ilmu Kelautan. Institut Pertanian Bogor.

Philips, J. 1972. Calory and Energy Recruitment in Fish Nutrition. Academic Press Inc. New York. 713p.

Putri, D. R. 2012. Kandungan Bahan Kering, Serat Kasar dan Protein Kasar pada Daun Lamtoro (Leucaena glauca) yang Difermentasi dengan Probiotik sebagai Bahan Pakan Ikan. Skripsi. Program Studi Budidaya Perairan. Fakultas Perikanan dan Kelautan. Universitas Airlangga. hal 61.

Rosmawati. 2005. Hidrolisis Pakan Buatan Oleh Enzim Pepsin dan Pankreas Untuk Meningkatkan Daya Cerna dan Pertumbuhan Benih Ikan Gurami (Osphronemus gouramy). Tesis. Sekolah Pasca Sarjana. Institut Pertania Bogor.

Sarmanu. 1986. Pengaruh Tepung Daun Lamtoro (Leucaena leucocephala) dan Mimosin Murni Terhadap Alat Reproduksi dan Produksi Ayam Petelur. Program Pascasarjana. Institut Pertanian Bogor. hal 139.

Suyanto, S. R. 2010. Pembenihan dan Pembesara Ikan Nila. Penebar Swadaya. Jakarta. hal 17.

Wardoyo, S. E. 2007. Ternyata Ikan Nila, Oreochromis niloticus Mempunyai Potensi yang Besar Untuk Dikembangkan. Media Akuakultur 2 (1) : 1 .

Zonneveld, N., E. A. Huisman dan J. H. Boon. 1991. Prinsip-prinsip Budidaya Ikan. PT Gramedia Pustaka Utama. Jakarta. hal. 48-90. 